
Hebräisch-Aramäisches

Taschenwörterbuch z. Alten Testament 1923 von Prof. D. Dr. Georg Beer

ca. $25 \mathrm{Bg}$.

Damit soll ein Gegenstück zu Preuschens Taschenwörterbuch zam Griechischen NT geschaffen werden, das sich gleich diesem rasch die Gunst seiner Benatzer erobern wird. Der Druck soll nächstens beginnen.

W. Brandt:

Die jüd. Baptismen oder das religiöse Waschen und Baden im Judentum mit Einschluß des Judenchristentums 1910. 154 Seiten. 6 M.

Judische Reinheitslehre und ihre Beschreibung in den Evangelien

1910. 71 Seiten. $2.70 \mathrm{M}$.

farl Bubde: Die altijaraelitiface Aeligion

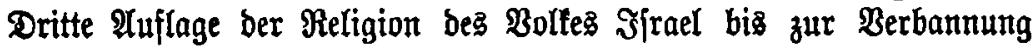
1912. 160 Seiten. $2.50 \mathrm{M}$.

Daz religiöle Reben Der Suden nach Dem (Eril

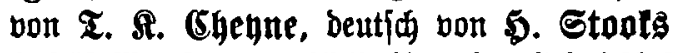

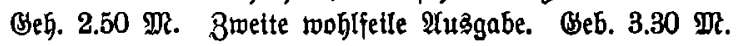

\section{Carl Clemen:}

\section{Die griechischen und lateinischen Nachrichten über die persische Religion}

Gedruckt mit Unterstützung des preuß. Ministeriums für Wissenschaft, Kunst und Volksbildung 1920. 240 Seiten. $40 \mathrm{M}$.

\section{Sermanm Cohen: \\ Deutfothtum und Sudentum}

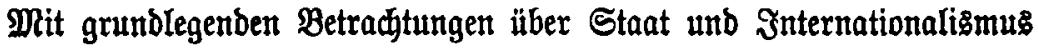

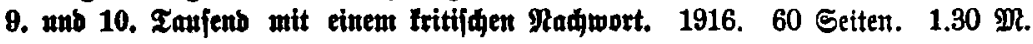

$\overline{Z u \text { den Preisen kommen noch die jeweilig gültigen Verlags-Teuerungszuschläge. }}$ 


\title{
DIE ENTSTEHUNG DER MANICHÄISCHEN RELIGION UND DES ERLÖSUNGSMYSTERIUMS
}

\author{
VON \\ I. SCHEFTELOWITZ
}

國

VERLAG VON ALFRED TÖPELMANN IN GIESSEN 1922 
Das Inhaltsverzeichnis befindet sich auf der letzten Seite. 